\title{
マイクロブログにおける流言の影響の分析
}

\section{宮部 真衣}

マイクロブログの普及により，ユーザは様々な情報を瞬時に取得することができる ようになった。一方，マイクロブログでは流言も拡散されやすい，流言は適切な情 報共有を阻害し，場合によっては深刻な問題を引き起こす恐れがある。これまで， マイクロブログ上の流言拡散に関する分析は多かったが，ある流言がどのような影 響を引き起こすかについての考察はない，本論文では，東日本大震災直後の Twitter を材料とし，どのような流言が深刻な影響を与えるかを，有害性と有用性という観 点からの主観評価および修辞ユニット分析により分析した。その結果，震災時の流 言テキストの多くは行動を促す内容や，状況の報告，予測であること，また，情報 受信者の行動に影響を与えうる表現を含む情報は，震災時に高い有用性と有害性を 持つ可能性があることを明らかにした。

キーワード：マイクロブログ，流言，災害

\section{Effects of Rumors on Microblogs}

\author{
Mai MiYabe $^{\dagger}$, Yayoi TANAKA ${ }^{\dagger \dagger}$, Sho Nishinata ${ }^{\dagger \dagger}$,

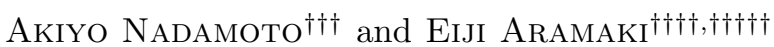

Microblogs have enabled us to exchange information in real time, which has led to the spread of not only beneficial but also potentially harmful information, such as rumors. Rumors may block the process of adequate information sharing, which may, in turn, cause serious problems. Several studies have already analyzed the impact of rumors on microblogging media; however, the way in which these rumors can cause potential problems largely remains unclear. This paper analyzes people' s perceptions of rumors on Twitter during disasters using subjective evaluation and rhetorical unit analysis. The results showed that many subjects perceived rumors as containing information that instigates people to take action, reports on a current situation, or predicts future events. Moreover, information that instigates people to take action has been perceived as beneficial in some contexts, while it is also seen as harmful in other cases.

Key Words: Microblogging system, Rumor, Disaster

\footnotetext{
†東京大学知の構造化センター, Center for Knowledge Structuring, The University of Tokyo

†† 神奈川大学外国語学部, Faculty of Foreign Languages, Kanagawa University

††甲南大学知能情報学部, Faculty of Intelligence and Informatics, Konan University

†††京都大学デザイン学ユニット, Design School, Kyoto University

††††† 科学技術振興機構さきがけ, JST PRESTO
} 


\section{1 はじめに}

近年, Twitter ${ }^{1}$ などのマイクロブログが急速に普及している．主に自身の状況や雑記などを 短い文章で投稿するマイクロブログは，ユーザの情報発信への敷居が低く，現在，マイクロブ ログを用いた情報発信が活発に行われている。2011年 3 月 11 日に発生した東日本大震災にお いては, 緊急速報や救援物資要請など, リアルタイムに様々な情報を伝える重要な情報インフ ラの 1 つとして活用された (インプレス R\&D 2011; 西谷 2010; 立入 2011). マイクロブログは, 重要な情報インフラとなっている一方で, 情報漏洩や流言の拡散などの問題も抱えている. 実 際に，東日本大震災においても，様々な流言が拡散された (荻上 2011)。流言については，これ までに多くの研究が多方面からなされている。流言と関連した概念として噂, 風評, デマといっ た概念がある。これらの定義の違いについては諸説あり, 文献毎にゆれているのが実情である. 本研究では, 十分な根拠がなく, その真偽が人々に疑われている情報を流言と定義し, その発 生過程（悪意をもった捏造か自然発生か）は問わないものとする。よって，最終的に正しい情 報であっても，発言した当時に，十分な根拠がない場合は，流言とみなす.

本論文では，マイクロブログの問題の 1 つである，流言に着目する，流言は適切な情報共有 を阻害する，特に災害時には，流言が救命のための機会を損失させたり，誤った行動を取らせ たりするなど，深刻な問題を引き起こす場合もある。 そのため，マイクロブログ上での流言の 拡散への対策を検討していく必要があると考えられる.

マイクロブログの代表的なツールとして, Twitter がある. Twitter は, 投稿する文章（以下， ツイート）が 140 字以内に制限されていることにより，一般的なブログと比較して情報発信の 敷居が低く(垂水 2010), またリツイート (RT) という情報拡散機能により, 流言が拡散されや すくなっている，実際に，東日本大震災においては，Twitter では様々な流言が拡散されていた が, 同じソーシャルメディアであっても, 参加者全員が同じ情報と意識を持ちやすい構造を採 用している mixi ${ }^{2}$ P Facebook ${ }^{3}$ で深刻なデマの曼延が確認されていないという指摘もある (小 林 2011).

マイクロブログ上での流言の拡散への対策を検討するためには，まずマイクロブログ上の流 言の特徵を明らかにする必要がある。そこで本論文では，マイクロブログとして，東日本大震 災時にも多くの流言が拡散されていたTwitter を材料に，そこから 481 件の流言テキストを抽 出した。

さらに, どのような流言が深刻な影響を与えるか, 有害性と有用性という観点から被験者によ る評価を行い, 何がその要因となっているか, 修辞ユニット分析の観点から考察を行った。 そ

\footnotetext{
1 http://twitter.com/

2 http://mixi.jp/

${ }^{3}$ http://www.facebook.com/
} 
の結果，震災時の流言テキストの多くは行動を促す内容や，状況の報告，予測であること，ま た，情報受信者の行動に影響を与えうる表現を含む情報は，震災時に高い有用性と有害性とい う全く別の側面を持つ可能性があることが明らかとなった。

以下， 2 章において関連研究について述べる．3 章では分析の概要について述べる．4 章で分 析結果を示し，マイクロブログ上での流言について考察する．5 章で将来の展望を述べ，最後 に 6 章で本論文の結論についてまとめる。

\section{2 関連研究}

本論文では，災害時のマイクロブログ上での流言について分析を行う。そこで本章では，ま ず，流言に関するこれまでの定義について述べた後，災害や流言について扱ったソーシャルメ ディアに関する研究について述べる.

\section{1 流言の定義と流言の伝達}

本節では，実社会における流言の先行研究について述べる.

流言の分類としては, ナップによる第 2 次世界大戦時の流言の分類がある (Knapp 1944).ナッ プは，流言を「恐怖流言 (不安や恐れの投影)」「願望流言 (願望の投影)」「分裂流言（憎しみ や反感の投影)」の 3 つに分類している。また，これらの流言がどのように流通するかは，例え ば不景気，災害など，社会状況に依存すると述べている。

また，社会状況だけでなく，流言の伝達に影響する要素として，流言の内容，特に，曖昧さ， 重要さ, 不安という3つの要因が知られている(川上 1997).オルポートとポストマンは, 流言 の流布量について, $R \sim i \times a$ のように定式化し,「流言の流布量 $(\mathrm{R})$ は, 重要さ (i) と曖昧さ (a)の積に比例する」と述べている (G.W.オルポート, L. ポストマン 2008).

このように，流言に関しては古くから研究が行われてきたが，主に口伝えでの流言の伝達を 対象としてきた。本論文では，口伝えより，より迅速に，また，広範囲に広まりうるネットワー ク上での流言を扱った点が新しい.

\section{2 災害, 流言とソーシャルメディア}

本節では，災害を扱ったTwitter をはじめとするソーシャルメディアの先行研究について概 観する。

災害時のソーシャルメディアの利用方法について分析した研究としては，まず Longuevilleら や Qu ら, Back ら, Cohn ら, Vieweg らの研究がある (De Longueville, Smith, and Luraschi 2009; Qu, Wu, and Wang 2009; Qu, Huang, Zhang, and Zhang 2011; Back, Kufner, and Egloff 2010; Cohn, Mehl, and Pennebaker 2004; Vieweg, Hughes, Starbird, and Palen 2010). Longueville 5 
は, 2009 年にフランスで発生した森林火災に関して, Twitter に発信されたツイートの分析を 行っている (De Longueville et al. 2009). この研究においては, ツイートの発信者の分類や, ツ イートで引用されたURLの参照内容に関する分析などを行っている，Quらは四川大地震およ び青海地震において中国のオンラインフォーラム $(\mathrm{BBS})$ がどのように利用されたのかを分析 している (Qu et al. 2009, 2011). また, Backらや Cohn らは, 9.11 時のブログの書き达み内容 を分析し, 人々の感情の変化を分析している (Back et al. 2010; Cohn et al. 2004). Vieweg ら (Vieweg et al. 2010) は, 2009 年のオクラホマの火事 (Oklahoma Grassfires) やレッドリバーで の洪水 (Red River Floods) における Twitterの利用方法を調査している。これらの研究では発 信された内容を分類し, 情報の発信の方法（情報発信か返信か）や，その位置関係について議 論しているが，情報が流言かどうかといった観点からの分析は行われていない.

流言については，災害時に限らず，多くのソーシャルメディア上の研究がある。 Qazvinian ら は，マイクロブログ (Twitter) における特定の流言に関する情報を網羅的に取得することを目的 とし，流言に関連するツイートを識別する手法を提案している (Qazvinian, Rosengren, Radev, and Mei 2011). Mendoza らは, 2010 年のチリ地震における Twitter ユーザの行動について分析 を行っている (Mendoza, Poblete, and Castillo 2010). この研究では, 正しい情報と流言に関す るツイートを, 「支持」「否定」「疑問」「不明」に分類し, 支持ツイート, 否定ツイートの数に ついて，正しい情報と流言との違いを分析している，分析結果として，正しい情報を否定する

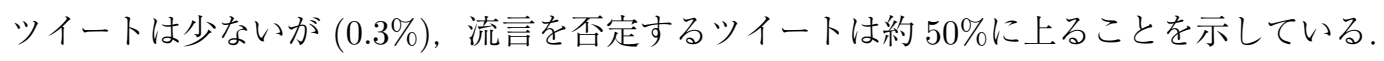

\section{3 分析の概要}

マイクロブログ上での流言拡散への対策を検討するためには，マイクロブログ上の流言の特 徵を明らかにする必要がある。まず，なぜ人間は流言を拡散させるのであろうか. 一般に，人々 がある情報を他者に伝える場合，その情報が正しいと思って伝えていることが多く，本人がでた らめだと思う話を，悪意をもって他者に伝えることは少ない(川上 1997)，また，流言とは，曖 昧な状況に巻き込まれた人々が，自分たちの知識や情報を寄せ集めることにより，その状況につ いて意味のある解釈を行おうとするコミュニケーションであるという考察もある (佐藤 2007). つまり，災害時の流言は，何らかの役に立ち得る（有用性のある）情報を含み, それを共有す るために善意で拡散されている可能性がある.

次に, 流言が拡散された場合, どのような問題が起きるかという点を考えると，1章で述べた ように，情報受信者を誤った行動に導き，様々な損失を与えるということが考えられる，つま り，特に対策を講じるべき流言とは，情報受信者にとって有害性のある情報である.

また，上述した何らかの役に立ち得る（有用性のある）情報は，人々の行動などに影響を与 える可能性もある。すなわち, 流言の内容が有用と判断される場合には, 情報受信者の何らか 
の行動を引き起こし得ると考えられ，有用性の高さは有害性と関連する可能性がある.

そこで本研究では，上述した「有害性」および「有用性」という観点に着目し，次の 2 つの 分析を行う。

（1）流言の有害性／有用性：どのような流言が有害または有用とみなされるのかの主観評価 を行う。

（2）流言の修辞ユニット分析：どのような特徵が先の有害性／有用性に影響を与えているの か, 後述する修辞ユニット分析という手法を用いて解析する。

\section{1 材料：対象データセット}

本研究では, 分析対象のデータとして, 東日本大震災ビッグデータワークショップにおいて Twitter Japan 株式会社により提供された，3月 11 日から 1 週間分のツイートデータを用いた.

1 章で述べたように，本論文では，十分な根拠がなく，その真偽が人々に疑われている情報 を流言と定義する。そこで，ある情報の真偽について言及しているツイートが投稿されている 場合，真偽を疑問視された内容は流言と見なし，それらを分析対象の流言として用いることと する。

流言は以下の手順で抽出した.

（1）データ全体から，情報の真偽について言及しているツイートをキーワード「デマ」をも

表 1 流言抽出のパターン

\begin{tabular}{|c|c|c|}
\hline & PTN1 & PTN2 \\
\hline 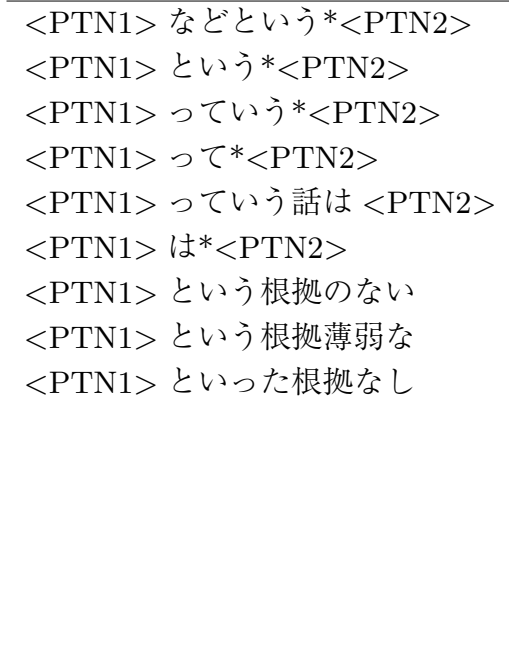 & $\begin{array}{c}\left.\Gamma^{*}\right\rfloor \\
『 * \rrbracket \\
\text { "** }\end{array}$ & $\begin{array}{l}\text { デマ } \\
\text { 嘘 } \\
\text { ツリ } \\
\text { 釣り } \\
\text { 偽情報 } \\
\text { ガセ } \\
\text { ネタ } \\
\text { 誤報 } \\
\text { 都市伝説 } \\
\text { ウソ } \\
\text { 狂言 } \\
\text { 迷信 } \\
\text { 間違い } \\
\text { いたずら } \\
\text { チェーンメール }\end{array}$ \\
\hline
\end{tabular}


表 2 抽出された流言の例

・タンクに貯蔵されていたのは LP ガスなので、人体に影響はない。

・関東の電気の備蓄が底をつく

・原発は安全だから避難はしなくていい

・近畿地方のプレートが小さくなって地震起こるって聞いたけど

・埼玉県の水道水が危ない、透明でも異物混入の可能性があり飲むな

表 3 同じ流言の表現のバリエーションの例

・うがい薬を飲むことは放射能に効果あり

・放射能污染をうがい薬を飲めば予防できる

・ヨウ素を含むうがい薬を飲めば、放射線被害は防げる

・ヨウ素の代わりに薬局で売っているうがい薬でも代替がききますよ

・放射能による健康被害を防ぐためヨウ素入りのうがい薬を飲むと良い

・安定ヨウ素剂の代わりに、ヨウ素を含むうがい薬やのどスプレー、ワカメなど海藻類の摂取が有効

とに抽出する 4 .

(2) 手順 (1) で抽出したツイートから, “「〜」というデマ”というパターンを用いて流言内 容（「〜」部）を抽出する. 用いたパターンは表 1 に示す.

(3) 抽出された流言内容を人手で確認し, 内容を理解可能なもののみを抽出する.

上記の手順により，486 件 5 の流言テキストを抽出した。抽出されたテキストの一部を表 2 に 示す。なお，本手順では，同じ流言の異なる表現のバリエーションも抽出されうる，例を表 3 に示す。本研究では，同じ流言を意図していても，伝え方によって印象が異なる可能性がある と考え，1つの流言に対する分析対象を 1 つのテキストとするのではなく，複数のテキストを 扱うこととする.

\section{2 分析 $1:$ 流言内容の影響度に関する主観評価}

前述したように，災害時の流言拡散において，実際的に問題となるのは，その流言が実際に 流言 (虚偽の情報) であった場合，どれくらい有害であるか，また，逆に，それが流言でなかっ た場合，どれくらい有用であるのかという 2 つの問題である.

そこで，以下の 2 項目について主観評価を実施した。

有害性：この情報が間違っている場合，この情報は人にとって有害である.

有用性：この情報が正しい場合，この情報は人にとって有用である.

4 今回は, 真偽を言及する際に「デマ」「流言」など特定のキーワードが用いられる可能性があると考え, 表 1 の PTN2 に相当する文字列を含むツイートを抽出した。

5 なお，抽出した 486 件の流言テキストのうち， 5 件は分析対象外としたため，実際の分析対象となった流言テキス 卜は 481 件である。詳細は 4 章で述べる。 
なお，本評価では，評価者自身にとって有害・有用でない情報であっても，ある人にとって有 害・有用であると考えられる場合は，有害・有用と判断してもらうこととした.

各項目の評価は, 5 段階評価 $(1:$ 強く同意しない, 2 : 同意しない, $3:$ どちらともいえない, 4 ：同意する， 5 ：強く同意する）を用いることとし，共著者を含む 7 名の評価者により評価を 行った。 また，評価者が上記のいずれの評価值もつけることができないと判断した場合，評価 不能 $(-1)$ とすることとした.

\section{3 分析 2 : 流言内容の分類}

分析 1 では, 流言の有害性と有用性という 2 つの尺度から, 流言について主観評価を行った。 次に問題となるのは，流言のどのような要素が有害性や有用性に影響を与えているかである. そこで, 2 つ目の分析として, 流言内容をいくつかの特徴から分析した. この際に, 先行研究で 観られた分類（行動を促進するかどうか，ネガティブな内容であるかどうか）に加え，知識伝 達の分析に用いられる修辞ユニット分析を用いた。

\subsection{1 従来の分類}

流言内容を分類した先行研究 (梅島, 宮部, 荒牧, 灘本 2011) では,「ネガティブである」「不 安を謆る」「行動を促進する」といった観点により流言の分類を行っている.

そこで，先行研究における分類に基づき，以下の 5 項目について主観評価を実施した. ネガティブさ：この情報はネガティブな内容である.

行動促進：この情報は行動を促している.

不安扇動：この情報は不安を㮼る。

尤もらしさ：この情報は尤もらしい.

伝聞情報：この情報には伝聞情報が含まれる.

各項目の評価は, 5 段階評価 $(1$ : 強く同意しない, 2 : 同意しない, $3:$ どちらともいえない, 4 ：同意する， 5 ：強く同意する）を用いることとし，共著者を含む 7 名の評価者により評価を 行った。

\subsection{2 修辞ユニット分析}

修辞ユニット分析（Rhetorical Unit Analysis 以下, RUA）(Cloran 1999) は, 談話分析手法の 1 つであり, 分析の過程で, 伝達される内容の修辞機能の特定を行い, 文脈化の程度を知るこ とができる。ここでいう文脈とは，一般的な話であるほど脱文脈化されており，個人的な話で あるほど文脈化されているとみなす巳度である。

例えば，「ホウ素は特殊な結晶構造をとるため放射線を吸収します。というのは一般性を持 つため脱文脈化されているとみなす。逆に，「ホウ素サプリを採りましょう」というのは聞き手 
に行動を促しており，文脈化されているとみなす。

先行研究では, 母子会話や生徒一教師の解析 (Cloran 1994, 1999, 2010), 作文指導 (佐野 2010), Q\&A サイトの解析 (田中, 佐野 2011a, 2011b, 2011; 田中 2011) などに用いられてきた. 日本語 への適用については文献 (佐野; 佐野, 小磯 2011) が詳しい. 本稿では, その概要のみを述べる ものとする。

RUA は通常次の手続きを踏む.

（1） 発話のメッセージ（基本的には節）の発話機能を認定し, 中核要素と現象定位を確認す る. 発話機能は,「与える」と「要求する」の「交換における役割」と, 「品物 $/$ 行為」と 「情報」という「交換されるもの」の二項の組み合わせで構成され，「品物／行為」の交 換を「提言」，「情報」の交換を「命題」とする (Halliday and Matthiessen 2004). 中核要

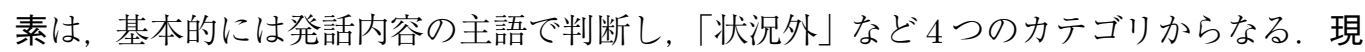
象定位は，発話機能が「命題」と認定されたメッセージについて，その発話内容の出来 事が起こった，あるいは起こる時を，基本的にはテンスや時間を表す副詞句などから判 断し，「過去」など 6 つのカテゴリからなる.

(2)この，発話機能と中核要素と現象定位の組み合わせから，14のレベルに細分化された修 辞機能が特定され，文脈化の程度（脱文脈化指数と呼ばれる）が測られる（表 4). 脱文 脈化指数の数值が大きいものほど脱文脈化の程度が高く一般的・汎用的で, 小さいもの ほど脱文脈化の程度が低く個人的・特定的である.

各修辞機能と脱文脈化指数へと分類されるテキストの例を以下に示す。[] 内は脱文脈化指数

表 4 修辞機能の特定と脱文脈化指数

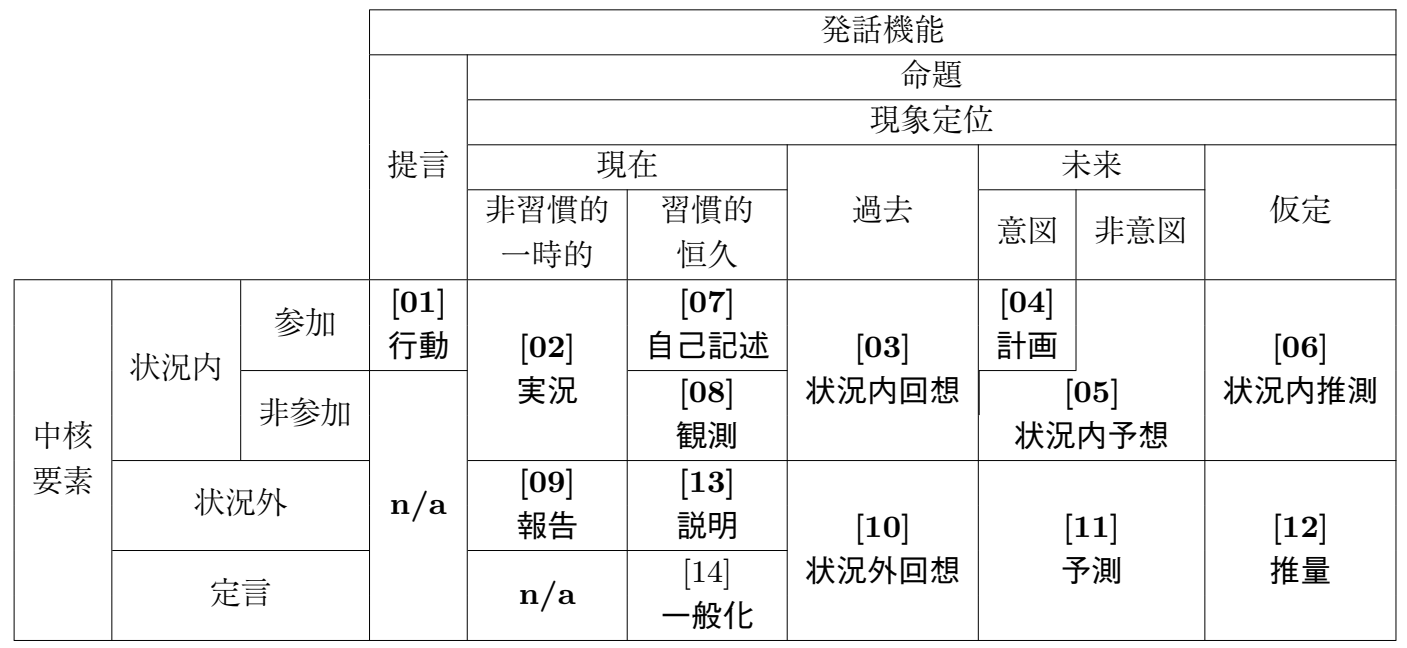

$\lceil\mathrm{n} / \mathrm{a} 」$ は該当なし/太字の部分が修辞機能の種類／[ ] 内は脱文脈化指数 
を示す。

[01］行動 みんなで節電しましょう

(中核要素対象：みんなで, 現象定位対象：節電しましょう)

[02］実況 血が流れている。

(中核要素対象：血が，現象定位対象：流れている)

[03］状況内回想 ラックが倒壊した。

(中核要素対象：ラックが, 現象定位対象：倒壊した）

[04］計画 お水買っといた方がいいんじゃない?

(中核要素対象： $\phi=$ あなたは（あるいはわたしは），現象定位対象：お水買っといた方 がいいんじゃない?）

[05］状況内予想 もうすぐ肉不足で焼肉食べられなくなる

(中核要素対象： $\phi=$ あなたは（あるいはわたしは），現象定位対象：もうすぐ肉不足で 焼肉食べられなくなる)

[06］状況内推測 放射能が来ても自転車のチューブがあれば助かるらしいぞ

(中核要素対象： $\phi=$ あなたは, 現象定位対象：自転車のチューブがあれば助かるらし いぞ)

［07］自己記述 国際線で 1 回飛ぶと宇宙線を 1 ミリシーベルト近く被曝します

(中核要素対象： $\phi=$ あなたは, 現象定位対象：宇宙線を 1 ミリシーベルト近く被曝し ます)

[08］観測 このそば屋の店主はいつも愛想がない

(中核要素対象：このそば屋の店主，現象定位対象：いつも愛想がない)

[09］報告 301 号にけが人がいます

(中核要素対象：けが人が，現象定位対象：います)

[10］状況外回想 阪神大震災の際ははじめの地震から三時間後に一番強い地震がきた

(中核要素対象：一番強い地震が, 現象定位対象：きた)

[11］予測 関東の方は深夜に地震が起きる可能性があるそうです。

（中核要素対象：地震が，現象定位対象：起きる可能性があるそうです）

[12］推量 首都圈で買いだめすると被災地に物資が届かなくなる

(中核要素対象：物資が，現象定位対象：届かなくなる)

[13］説明 日本ユニセフ協会は募金をピンハネする

（中核要素対象：日本ユニセフ協会は，現象定位対象：募金をピンハネする）

［14］一般化 ホウ素は特殊な結晶構造をとるため放射線を吸収します。

(中核要素対象：ホウ素は，現象定位対象：特殊な結晶構造をとるため放射線を吸収し ます。) 
なお，修辞ユニット分析については，修辞ユニット分析に精通した 1 名の作業者が分類作業 を行った。

\section{4 分析結果と考察}

本論文では, 分析 1 における評価結果において, 評価者 7 名の内 4 名以上が判定不能と判断 したもの，および分析 2 における修辞機能と脱文脈化指数の認定ができなかったものは分析対 象から除外することとした. 確認の結果, 分析 1 において評価者 4 名以上が判定不能と判断し たものは存在しなかったため, 分析 2 における修辞機能と脱文脈化指数の認定ができなかった 5 件のみを除外した，481件の流言テキストを分析対象とした。 また，分析 1 の評価結果につい ては， 7 名の評価者による全ての評価結果 $(481$ 件 $\times 7$ 名分， 3,367 件）および 7 名による評価 結果の中央值を用いて考察する ${ }^{6}$.

\section{1 流言内容の影響度に関する主観評価結果}

本節では，分析 1 （流言内容の影響度に関する主観評価）の結果について述べる。流言テキ ストの有害性，有用性に関する主観評価結果を表 5 に示す。表 5 より，481件に対する 7 名の 全評価值 5）が多い傾向が見られる。また，481件の各流言テキストに対する評価值の代表值として，中 央值をとった場合の分類結果を見ると, 全評価值と同様に, 有害性, 有用性のどちらも「同意

表 5 有害性, 有用性に関する分類結果

\begin{tabular}{|c|c|c|c|c|c|c|c|c|c|c|}
\hline \multirow[b]{2}{*}{ 評価項目 } & & \multicolumn{9}{|c|}{5 段階評価值 } \\
\hline & & $\begin{array}{c}1 \\
\text { (件) }\end{array}$ & $\begin{array}{l}1.5 \\
\text { (件) }\end{array}$ & $\begin{array}{c}2 \\
\text { (件) }\end{array}$ & $\begin{array}{l}2.5 \\
\text { (件) }\end{array}$ & $\begin{array}{c}3 \\
\text { (件) }\end{array}$ & $\begin{array}{c}3.5 \\
\text { (件) }\end{array}$ & $\begin{array}{c}4 \\
\text { (件) }\end{array}$ & $\begin{array}{c}4.5 \\
\text { (件) }\end{array}$ & $\begin{array}{c}5 \\
\text { (件) }\end{array}$ \\
\hline \multirow{2}{*}{ 有害性 } & 中央值 & 15 & 4 & 93 & 12 & 82 & 7 & 225 & 7 & 36 \\
\hline & 全評価値 & 262 & 0 & 829 & 0 & 397 & 0 & 1017 & 0 & 726 \\
\hline \multirow{2}{*}{ 有用性 } & 中央值 & 14 & 3 & 44 & 3 & 58 & 12 & 291 & 7 & 49 \\
\hline & 全評価値 & 237 & 0 & 348 & 0 & 369 & 0 & 1499 & 0 & 797 \\
\hline
\end{tabular}

·各評価值は, 1 : 強く同意しない, 2 : 同意しない, $3:$ どちらともいえない, $4:$ 同意する, $5:$ 強く同意 する，を意味する。

·「判定不能」と評価した評価者がいた場合，その值は除外して中央値を取っている．表中の $1.5,2.5,3.5$, 4.5 欄は，除外後の評価結果が偶数個の場合の中央值（中央に近い 2 つの值の算術平均）である.

\footnotetext{
6 なお, 評価者が「判定不能」と評価した場合, 中央值の算出や頻度の計算においては, その評価値は除外する.

7 表中の該当数の合計が全評価結果数 (3,367 件) に満たないのは,「判定不能」と評価されたものは除外しているた めである.
} 
する」（評価值 4 または 5）に分類された流言が多く，震災時に発信された流言テキストは，有 害性や有用性が高い傾向が見られる.

また， 481 件に対する 7 名の有害性，有用性の評価結果ペア（3,367ペア）をもとに順位相関 係数を調査した結果，順位相関係数は 0.601 であり，正の相関がみられた。また，流言テキス 卜 1 件毎に中央值をとった場合の，481ペアの有害性，有用性評価結果の順位相関係数は 0.628 となり，同様に正の相関がみられた。有害性評価と有用性評価の分布を表 6,7 に示す。表 6 , 7 より，一部，有害性と有用性の分類結果に相関がみられないものも見られる。例えば，「ほく でんが東京電力に電力提供する準備を始めた」という流言テキストは，有害性の評価結果（中 央值）は 2 であったが, 有用性の評価結果（中央值）は 4 であった。 また,「韓国で日本の大地

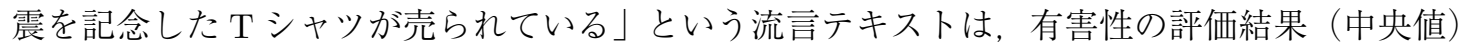
は 4 であったが, 有用性の評価結果（中央值）は 2 であった。 これらの一部例外となる流言テ キストはあるものの，大部分の流言テキストについては，有害性と有用性の分類結果は類似し ている。つまり，有用性と有害性は表裏一体の関係にあることが多く，情報が正しい場合に有

表 6 有害性評価と有用性評価の分布（中央值を用いた場合）

\begin{tabular}{c|c|rrrrrrrrrr}
\hline \multicolumn{2}{c|}{} & \multicolumn{10}{c}{ 有害性 } \\
\cline { 3 - 12 } \multicolumn{1}{c}{} & 1 & 1.5 & 2 & 2.5 & 3 & 3.5 & 4 & 4.5 & 5 & 計 \\
\hline \multirow{5}{*}{ 有用性 } & 1 & 11 & 0 & 3 & 0 & 0 & 0 & 0 & 0 & 0 & 14 \\
& 1.5 & 0 & 2 & 1 & 0 & 0 & 0 & 0 & 0 & 0 & 3 \\
& 2 & 0 & 1 & 34 & 1 & 5 & 0 & 3 & 0 & 0 & 44 \\
& 2.5 & 1 & 0 & 1 & 1 & 0 & 0 & 0 & 0 & 0 & 3 \\
& 3.5 & 3 & 0 & 26 & 2 & 10 & 1 & 16 & 0 & 0 & 58 \\
& 4 & 0 & 0 & 1 & 4 & 4 & 3 & 0 & 0 & 0 & 12 \\
& 4.5 & 0 & 0 & 0 & 1 & 1 & 1 & 2 & 0 & 2 & 7 \\
& 5 & 0 & 0 & 0 & 0 & 0 & 1 & 35 & 2 & 11 & 49 \\
\hline & 計 & 15 & 4 & 93 & 12 & 82 & 7 & 225 & 7 & 36 & 481 \\
\hline
\end{tabular}

表 7 有害性評価と有用性評価の分布（7 名の全評価結果）

\begin{tabular}{r|r|rrrrr|r}
\hline \multicolumn{2}{c|}{} & \multicolumn{7}{|c}{ 有害性 } \\
\cline { 3 - 8 } \multicolumn{1}{c}{} & \multicolumn{1}{c|}{1} & \multicolumn{1}{c}{3} & 3 & 4 & 5 & 計 \\
\hline \multirow{6}{*}{ 有用性 } & 1 & 197 & 24 & 2 & 4 & 5 & 232 \\
& 2 & 30 & 188 & 33 & 76 & 16 & 343 \\
& 3 & 8 & 61 & 145 & 115 & 34 & 363 \\
& 4 & 18 & 540 & 168 & 614 & 152 & 1,492 \\
& 5 & 7 & 15 & 49 & 207 & 518 & 796 \\
\hline & 計 & 260 & 828 & 397 & 1016 & 725 & 3,226 \\
\hline
\end{tabular}


用性の高い内容は，その情報が間違っていた場合に有害となりうると言える.

\section{2 流言内容の分類結果}

本節では，分析 2 （流言内容の分類）の結果について述べる。まず，先行研究に基づく流言 内容の主観評価結果を表 8 に, 各項目および有害性, 有用性の評価結果の順位相関係数を表 9 , 10 にそれぞれ示す。

表 8 より，震災時に流れた流言内容は，ネガティブで, 不安を煽るものであることがわかる. これは, 先行研究における結論 (G.W. オルポート, L. ポストマン 2008) と一致する.

なお, 表 9,10 に示した各項目と有害性, 有用性の評価結果の相関を見ると, 中央值を用いた

表 8 主観評価による分類結果

\begin{tabular}{|c|c|c|c|c|c|c|c|c|c|c|}
\hline \multirow[b]{2}{*}{ 評価項目 } & & \multicolumn{9}{|c|}{5 段階評価值 } \\
\hline & & $\begin{array}{c}1 \\
\text { (件) }\end{array}$ & $\begin{array}{l}1.5 \\
\text { (件) }\end{array}$ & $\begin{array}{c}2 \\
\text { (件) }\end{array}$ & $\begin{array}{l}2.5 \\
\text { (件) }\end{array}$ & $\begin{array}{c}3 \\
(\text { 件) }\end{array}$ & $\begin{array}{l}3.5 \\
\text { (件) }\end{array}$ & $\begin{array}{c}4 \\
\text { (件) }\end{array}$ & $\begin{array}{l}4.5 \\
\text { (件) }\end{array}$ & $\begin{array}{c}5 \\
\text { (件) }\end{array}$ \\
\hline \multirow{2}{*}{ ネガティブさ } & 中央值 & 14 & 1 & 44 & 11 & 87 & 3 & 158 & 4 & 159 \\
\hline & 全評価值 & 214 & 0 & 265 & 0 & 624 & 0 & 1,191 & 0 & 993 \\
\hline \multirow{2}{*}{ 行動促進 } & 中央值 & 4 & 22 & 115 & 98 & 72 & 10 & 141 & 1 & 18 \\
\hline & 全評価值 & 514 & 0 & 588 & 0 & 733 & 0 & 875 & 0 & 348 \\
\hline \multirow{2}{*}{ 不安扇動 } & 中央值 & 13 & 5 & 56 & 5 & 70 & 7 & 176 & 3 & 146 \\
\hline & 全評価値 & 272 & 0 & 308 & 0 & 410 & 0 & 1,418 & 0 & 889 \\
\hline \multirow{2}{*}{ 尤もらしさ } & 中央值 & 6 & 4 & 211 & 5 & 206 & 1 & 48 & 0 & 0 \\
\hline & 全評価値 & 287 & 0 & 1,361 & 0 & 741 & 0 & 930 & 0 & 22 \\
\hline \multirow{2}{*}{ 伝聞情報 } & 中央值 & 1 & 0 & 223 & 4 & 209 & 0 & 38 & 1 & 5 \\
\hline & 全評価值 & 214 & 0 & 1,450 & 0 & 1,107 & 0 & 440 & 0 & 136 \\
\hline
\end{tabular}

- 各評価值は, 1 : 強く同意しない, 2 : 同意しない, $3:$ どちらともいえない, $4:$ 同意する, $5:$ 強く同意 する，を意味する。

·「判定不能」と評価した評価者がいた場合，その值は除外して中央値を取っている．表中の $1.5,2.5,3.5$, 4.5 欄は, 除外後の評価結果が偶数個の場合の中央值（中央に近い 2 つの值の算術平均）である.

表 9 主観評価結果の相関係数（中央值を用いた場合）

\begin{tabular}{l|cc|ccccc}
\hline & 有害性 & 有用性 & ネガティブさ & 行動促進 & 不安扇動 & 尤もらしさ & 伝聞情報 \\
\hline 有害性 & 1.000 & & & & & & \\
有用性 & 0.628 & 1.000 & & & & & \\
ネガティブさ & 0.340 & 0.372 & 1.000 & & & & \\
行動促進 & 0.436 & 0.507 & 0.079 & 1.000 & & & \\
不安扇動 & 0.386 & 0.434 & 0.884 & 0.137 & 1.000 & & \\
尤もらしさ & 0.068 & 0.159 & 0.207 & 0.157 & 0.231 & 1.000 & \\
伝聞情報 & 0.138 & 0.093 & 0.233 & 0.035 & 0.266 & 0.288 & 1.000 \\
\hline
\end{tabular}


場合は, 行動促進と有害性, 有用性との間や, 不安扇動と有用性との間に相関が見られる. 全 評価值を用いた場合の上記の関連は，中央值を用いた場合よりも相関は弱くなるものの，同様 の傾向が見られる.

一方，尤もらしさや伝聞情報に関しては，上述した指標と比較して相関が弱く，これらの影 響で有害性や有用性が決定されているわけでないと言える.

次に，修辞ユニット分析による分類結果を表 11 に示す.

まず，脱文脈化指数の観点から考察する．3.3.2 項で述べたように，脱文脈化指数は，数值が 大きいものほど一般的・汎用的で，小さいものほど個人的・特定的であるとされる．表 11 を見

表 10 主観評価結果の相関係数（全評価値を用いた場合）

\begin{tabular}{l|cc|ccccc}
\hline & 有害性 & 有用性 & ネガティブさ & 行動促進 & 不安扇動 & 尤もらしさ & 伝聞情報 \\
\hline 有害性 & 1.000 & & & & & & \\
有用性 & 0.601 & 1.000 & & & & & \\
ネガティブさ & 0.303 & 0.277 & 1.000 & & & & \\
行動促進 & 0.324 & 0.375 & -0.001 & 1.000 & & & \\
不安扇動 & 0.336 & 0.383 & 0.790 & 0.056 & 1.000 & & \\
尤もらしさ & 0.233 & 0.115 & -0.006 & 0.124 & 0.050 & 1.000 & \\
伝聞情報 & 0.170 & 0.028 & 0.123 & 0.078 & 0.143 & 0.231 & 1.000 \\
\hline
\end{tabular}

表 11 修辞機能と脱文脈化指数による分類結果

\begin{tabular}{l|rc}
\hline 修辞機能 ([] 内は脱文脈化指数) & $\begin{array}{c}\text { 該当数 } \\
(\text { 最大值 })\end{array}$ & $\begin{array}{c}\text { 該当数 (最小值) } \\
(\text { 件 })\end{array}$ \\
\hline$[01]$ 行動 & 64 & 108 \\
{$[02]$ 実況 } & 25 & 22 \\
{$[03]$ 状況内回想 } & 4 & 3 \\
{$[04]$ 計画 } & 8 & 9 \\
{$[05]$ 状況内予想 } & 8 & 8 \\
{$[06]$ 状況内推測 } & 9 & 9 \\
{$[07]$ 自己記述 } & 1 & 1 \\
{$[08]$ 観測 } & 0 & 0 \\
{$[09]$ 報告 } & 120 & 107 \\
{$[10]$ 状況外回想 } & 99 & 91 \\
{$[11]$ 予測 } & 114 & 102 \\
{$[12]$ 推量 } & 11 & 8 \\
{$[13]$ 説明 } & 17 & 13 \\
{$[14]$ 一般化 } & 1 & 0 \\
\hline
\end{tabular}

* 修辞ユニット分析は節ごとに分類を行うため, 1 つのツイートに複数の修辞機能が認定され，脱文脈化 指数が付与される場合がある。 そこで, 表 11 には 1 つのツイートに付与された脱文脈化指数のうち, 最 大值および最小值を代表值とした場合の該当数を提示している. 
ると, 各脱文脈化指数に分類される流言テキストの数にはばらつきがみられ，発信された流言 について, 各脱文脈化指数の大きさとの関連は見られなかった。つまり, 内容が一般的か，個 人的かに関わらず，流言は発信されると考えられる。

次に，修辞機能の観点から考察する，表 11 より，[01] 行動，[09] 報告, [10] 状況外回想, [11] 予測に分類されたものが合計 397 件（代表值が最大值の場合）および 408 件（代表值が最小値 の場合）で, 代表值を最大值, 最小值とした場合のいずれについても, 分析対象の $80 \%$ 以上と なる.つまり, 震災時の流言のカテゴリは 4 つ（行動を促す内容, 状況の報告, 状況外回想, 予測）が大部分を占めていることがわかる.

\section{3 修辞機能と脱文脈化指数による分類結果から見た有害性, 有用性}

本節では, 修辞機能抢よび脱文脈化指数による分類結果をもとに, 有害性, 有用性との関連 について考察する．修辞ユニット分析は節ごとに分類を行うため，1つのッイートに複数の修 辞機能が特定され脱文脈化指数が付与される場合がある，表 11 に示したように，代表值を最大 值，最小值とした場合の分布は類似している。それぞれの結果をもとに有害性，有用性との関 連を確認した結果，いずれも同様の傾向を示したが，最小值を用いた場合により顕著な傾向が 見られたため, 以降の分析では脱文脈化指数の最小值を代表値とした場合の分類結果をもとに 議論する.

\section{有害性との関連}

図 1 に, 有害性の各評価値に分類された流言に関する, 修辞機能と脱文脈化指数の割合を示 す。な扮, 図 1 では, 有害性の評価結果（中央值）に基づき, 有害性の低いもの（評価值 $1,1.5$, 2), 中程度のもの（評価值 $2.5 ， 3 ， 3.5$ ）, 高いもの（評価值 4，4.5，5）に分類されたものをま とめた際の修辞機能と脱文脈化指数の割合を提示している。各評価值における修辞機能と脱文 脈化指数の割合については, 付録に扔ける図 3 として提示している，また，分類結果の例とし て, [01] 行動と [09] 報告の例を表 12 に示す.

図 1 より, 有害性が高いと評価された流言（評価值 4 5) は, 修辞機能と脱文脈化指数の分 類結果としては, [01] 行動に約 30\%が，[11] 予測に約 $25 \%$ の流言が分類されている。ここでい う行動には注意喚起や救援要請など, 情報受信者の行動を促進するものが含まれ（表 12）, こ の結果は，4.2節で述べた，行動促進が有害性と相関していることを裏付けている.

逆に，有害性が低いと評価された流言（評価値 1 2）の $70 \%$ 程度は, 修辞機能と脱文脈化指 数が [09] 報告や $[10]$ 状況外回想に分類されている.

このように, 本結果から, 行動促進のみが有害性と相関するだけでなく, 有害性を低くする 要素として，回想や報告があることが伺える． 


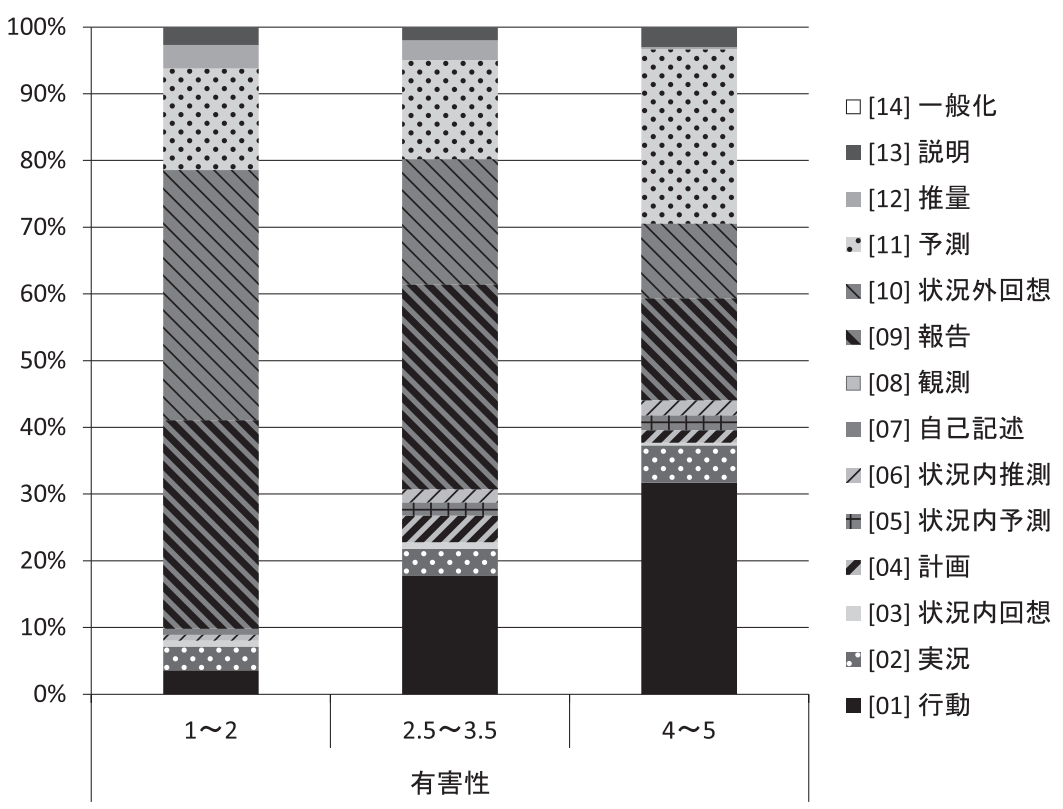

図 1 有害性と修辞機能および脱文脈化指数

表 12 有害性評価結果における特徵的な分類結果の例

\begin{tabular}{|c|c|c|}
\hline 流言テキスト & $\begin{array}{l}\text { 修辞機能と } \\
\text { 脱文脈化指数 }\end{array}$ & $\begin{array}{c}\text { 有害性 } \\
\text { 評価結果 }\end{array}$ \\
\hline $\begin{array}{l}\text { コスモ石油の社員からの連絡です。タンクの爆発で有害物質が天と } \\
\text { 一緒にふるから気をつけてください。 }\end{array}$ & [01] 行動 & 4 \\
\hline 関西電力が関東に電気を送るから節電しろ & [01] 行動 & 4 \\
\hline サーバの下敷きになってる!助けて! & [01] 行動 & 4 \\
\hline 原発は安全だから避難はしなくていい & [01] 行動 & 5 \\
\hline 埼玉県の水道水が危ない、透明でも異物混入の可能性があり飲むな & [01] 行動 & 5 \\
\hline $\begin{array}{l}\text { 青森から茨城、千葉まで津波が来てます！高台に逃げてください！山 } \\
\text { に逃げてください！3 階以上に！自衛隊のヘリコプターが津波（波） } \\
\text { を確認しました！ }\end{array}$ & [01] 行動 & 5 \\
\hline $\begin{array}{l}\text { スーパーの菓子コーナーが空になる中、きのこの山だけが山積みで } \\
\text { 残ってる }\end{array}$ & [09] 報告 & 1 \\
\hline ワンピースの作者が 15 億円寄付 & [09] 報告 & 1 \\
\hline フジテレビへの募金はユニセフへ送られる & [09] 報告 & 1 \\
\hline 実は報道されてないけど九州が大変らしいよ & [09] 報告 & 2 \\
\hline 築地に魚が余っている & [09] 報告 & 2 \\
\hline 既にいくつかの学生団体が現地入りしている & [09] 報告 & 2 \\
\hline
\end{tabular}




\section{有用性との関連}

図 2 に，有用性の各評価值に分類された流言に関する，修辞機能と脱文脈化指数の割合を示 す. 図 2 についても, 図 1 と同様に, 有用性の評価結果（中央值）に基づき, 有用性の低いも の（評価值 $1 ， 1.5 ， 2 ）$, 中程度のもの（評価值 $2.5 ， 3 ， 3.5 ）$, 高いもの（評価值 $4,4.5,5 ） に$ 分類されたものをまとめた際の修辞機能と脱文脈化指数の割合を提示している。各評価值にお ける修辞機能と脱文脈化指数の割合については，付録における図 4 として提示する.

先の有害性と同じく, 有用性が高いと評価された流言の $30 \%$ 前後が [01] 行動に, $25 \%$ 程度が [11] 予測に分類され，有用性が低いと評価された流言の $74 \%$ 程度が [09] 報告や [10] 状況外回想 に分類された. 表 13 に，分類結果の例として [10] 状況外回想と [11] 予測の例を示す.

このように，有害性と有用性は基本的には同様の傾向を示すことがわかった.

\section{有害性, 有用性と修辞機能との関連のまとめ}

以上の有害性, 有用性との関連の結果から, 行動を促すテキストおよび将来発生し得る事象 の予測を含むテキストは，震災時高い有用性と有害性を持つと判断される。また，回想や報告 を含むテキストは，震災時の有用性と有害性が低い傾向がある。つまり，情報受信者の未来の 行動に影響を与えうる表現を含む情報は, 震災時に高い有用性と有害性を持ち, 過去に発生し たことの報告については, 有用性・有害性が低いと考えられる.

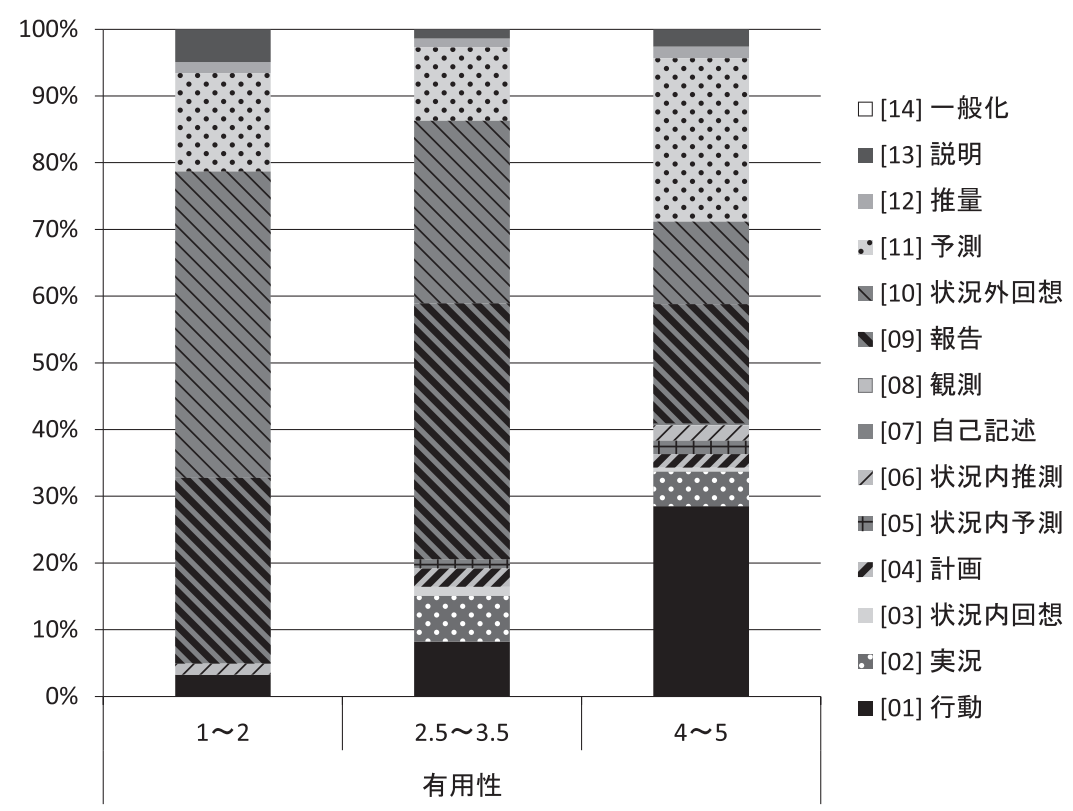

図 2 有用性と修辞機能および脱文脈化指数 
表 13 有用性評価結果における特徵的な分類結果の例

\begin{tabular}{|c|c|c|}
\hline 流言テキスト & $\begin{array}{l}\text { 修辞機能と } \\
\text { 脱文脈化指数 }\end{array}$ & $\begin{array}{c}\text { 有用性 } \\
\text { 評価結果 }\end{array}$ \\
\hline 記者会見によく出てくる原子力安全保安院の人が実はヅラだった & [10] 状況外回想 & 1 \\
\hline レディー・ガガが 1 億円寄付 & [10] 状況外回想 & 1 \\
\hline 枝野官房長官 105 時間ぶりに就寝 & [10] 状況外回想 & 1 \\
\hline 静岡の浜岡原発は地震に弱いって話してる 2 人組がいたよ & [10] 状況外回想 & 2 \\
\hline 台湾からの義援金拒否 & [10] 状況外回想 & 2 \\
\hline 政府が日野のガイガーのサイトを遮断した & [10] 状況外回想 & 2 \\
\hline 近畿地方のプレートが小さくなって地震起こるって聞いたけど & [11] 予測 & 4 \\
\hline 自衛隊に（食料とか）持っていけば寄付してもらえると聞いたんで & [11] 予測 & 4 \\
\hline 豊川信用金庫が倒産する & [11] 予測 & 4 \\
\hline 水戸地区は明日から平日 16 時から 19 時まで停電の予定 & [11] 予測 & 5 \\
\hline トイレットペーパーが無くなるかも & [11] 予測 & 5 \\
\hline 富山県内で 13 日大地震が発生する & [11] 予測 & 5 \\
\hline
\end{tabular}

*「〜と聞いた」のような形式のテキストについては,「〜」の部分が分析対象となる.

\section{4 表現の違いによる影響}

3.1 節で述べたように，本論文における抽出手順では，同じ流言の異なる表現のバリエーショ ンも抽出されうる。本論文では，同じ流言を意図していても，伝え方によって印象が異なる可 能性があると考え，1つの流言に対する分析対象を 1 つのテキストに限定せず，複数のテキス 卜を扱った。しかし，同じ流言を意図する表現が大量に含まれる場合，それらが結果に影響す る可能性がある。そこで，本節では，1つの流言に対するテキストを限定した場合の結果につ いて述べる。

まず，表 3 に示したような，同じ内容を取り扱っているが異なる表現を持つものを 1 つの流 言と見なした場合の，データセット中の流言数を確認した。流言テキストに含まれるキーワー ドをもとに分類し，さらに人手で内容を確認しながら流言内容毎の表現バリエーション数を調 査した。確認の結果，481 件の流言テキストに含まれる独立した流言内容は 256 件であった. 表 14 に，表現バリエーション数を示す．2つ以上の表現バリエーションを持つ流言内容は 256 件中 44 件であり，1つの流言内容に対する最大の表現バリエーション数は, 81 バリエーション であった。

次に，複数の表現バリエーションを持つ流言内容から，代表となるテキストをランダムに抽 出した。なお，同じ流言を意図する複数の表現が，すべて同じ修辞機能に認定されるとは限ら ない，修辞機能により違いがある可能性もあるため, 今回はある流言に対して単純に 1 つのテ キストを抽出するのではなく, 修辞機能に違いのあるテキストが含まれる場合は, 修辞機能ご とに 1 つずつ抽出することとした，上記の条件で抽出されたテキストは 300 件である。 
表 14 表現バリエーション数

\begin{tabular}{c|c}
\hline 表現バリエーション数 & 該当流言内容数 $($ 件 $)$ \\
\hline 1 & 212 \\
2 & 22 \\
3 & 9 \\
4 & 3 \\
5 & 1 \\
6 & 0 \\
7 & 1 \\
8 & 1 \\
9 & 1 \\
10 以上 & 6 \\
\hline 合計 & 256 \\
\hline
\end{tabular}

300 件のテキストを用いて，4.1 節〜 4.3 節と同様の分析を行った結果， 4.1 節〜 4.3 節で示し た結果と同様の傾向が見られた ${ }^{8}$. したがって，今回の分析においては，流言における複数の表 現は，分析結果に大きな影響は与えていないと考えられる。

\section{5 分析結果の限定性}

本章では，震災時の流言テキストを対象として流言内容の主観評価，分類を行い，流言テキ ストの持ち得る性質についてまとめた.

本論文で得られた結果は, 流言テキストのみを対象として調査した結果得られたものであり, 流言ではないものについても，今回明らかにした流言テキストと同様の性質を持つ可能性もあ る。つまり，本論文で得られた結論が，流言のみにあてはまるものであるかどうかという点ま では，本論文では検証できていない，今後，流言以外のテキストを対象とした調査を行い，流 言との違いの有無を確認し，今回得られた結論が流言のみに限定されるものか，テキスト全般 に適用されるものかを明らかにする必要がある。

\section{5 将来への展望}

本研究により, 流言において, 有害性と有用性に影響を与える要素として, 行動の促進, 予 測があることが分かった。一部の行動を促す表現は「〜して下さい」「に注意!」など，典型な 表現を含んでいるため, 本研究の知見により, 大量の流言の中から, 有害または有用であるも のをある程度ピックアップすることも可能だと思われる.

\footnotetext{
${ }^{8} 300$ 件のテキストによる結果については, 付録として提示する.
} 
我々は自動的に流言を収集するサービスをすでに動かしているが(宮部，梅島，灘本，荒牧 2011, 2012), 今後, 本知見による有害性, 有用性推定システムを組み込む予定である.

\section{6 おわりに}

本研究では, マイクロブログ上での流言の特徵を明らかにするために, Twitter を例とした分 析を行った，分析対象として，東日本大震災時の Twitter データから抽出した 481 件の流言テ キストを用いた。流言テキストに対する主観評価および修辞ユニット分析を行い，震災時に発 生したマイクロブログ上の流言テキストには，以下の傾向があることを明らかにした。

（1）情報が正しい場合に有用性の高い内容は，その情報が間違っていた場合に有害性がある.

(2) 震災時に拡散する流言テキストは, 行動を促す内容や, 状況の報告, 回想, 予測が大部 分を占める.

（3）情報受信者の行動に影響を与えうる表現，または，予想を含む情報は，高い有用性と有 害性を持つと考えられる。

ただし，上記の結論は，流言テキストのみを対象として調査した結果得られたものであり，こ れらの性質が流言のみにあてはまるものであるかどうかは不明である.

今後は，流言以外のテキストを対象とした調査を行い，上述した結論が流言のみに限定され るものなのかどうかの検証が必要である。また，得られた知見に基づき，流言拡散を防ぐため の仕組みを検討していく必要がある.

\section{謝 辞}

本研究の一部は, JST 戦略的創造研究推進事業による.

\section{参考文献}

Back, M. D., Kufner, A. C. P., and Egloff, B. (2010). "The Emotional Timeline of September 11, 2001." Psychological Science, 21 (10), pp. 1417-1419.

Cloran, C. (1994). Rhetorical units and decontextualisation: an enquiry into some relations of context, meaning and grammar. Ph.D. thesis, Nottingham University.

Cloran, C. (1999). "Instruction at home and school." In Christie, F. (Ed.), Pedagogy and the shaping of consciousness: Linguistic and social processes, pp. 31-65. Cassell, London.

Cloran, C. (2010). "Rhetorical unit analysis and Bakhtin's chronotype." Functions of Language, 17 (1), pp. 29-70. 
Cohn, M. A., Mehl, M. R., and Pennebaker, J. W. (2004). "Linguistic Markers of Psychological Change Surrounding September 11, 2001." Psychological Science, 15 (10), pp. 687-693.

De Longueville, B., Smith, R. S., and Luraschi, G. (2009). " "OMG, from here, I can see the flames!": a use case of mining location based social networks to acquire spatio-temporal data on forest fires." In Proceedings of the 2009 International Workshop on Location Based Social Networks, LBSN '09, pp. 73-80. ACM.

G.W.オルポート, L. ポストマン (2008). デマの心理学. 岩波書店.

Halliday, M. A. K. and Matthiessen, C. M. I. M. (2004). An introduction to functional grammar (3rd ed edition). Arnold, Hodder Education.

インプレス R\&D インターネットメディア総合研究所 (2011). インターネット白書 2011. イン プレスジャパン.

川上善郎 (1997). うわさが走る 情報伝搬の社会心理. サイエンス社.

Knapp, R. H. (1944). "A Psychology of Rumor." Public Opinion Quarterly, 8 (1), pp. 22-37. 小林啓倫 (2011). 災害とソーシャルメディア〜混乱、そして再生へと導く人々の「つながり」〜. 毎日コミュニケーションズ.

Mendoza, M., Poblete, B., and Castillo, C. (2010). "Twitter under crisis: can we trust what we RT?" In Proceedings of the First Workshop on Social Media Analytics, SOMA '10, pp. 71-79. ACM.

宮部真衣, 梅島彩奈, 灘本明代, 荒牧英治 (2011). 流言訂正情報に基づいた流言情報クラウド の提案. 第 4 回楽天研究開発シンポジウム, pp. 1-4.

宮部真衣，梅島彩奈，灘本明代，荒牧英治 (2012). 人間による訂正情報に着目した流言拡散防 止サービスの構築. マルチメディア，分散，協調とモバイル（DICOMO2012）シンポジウ 厶, pp. $1442-1449$.

西谷智広 (2010). I 見聞録：Twitter 研究会. 情報処理学会誌, 51 (6), pp. 719-724. 荻上チキ (2011). 検証 東日本大震災の流言・デマ. 光文社新書.

Qazvinian, V., Rosengren, E., Radev, D. R., and Mei, Q. (2011). "Rumor has it: Identifying Misinformation in Microblogs." In EMNLP, pp. 1589-1599. ACL.

Qu, Y., Huang, C., Zhang, P., and Zhang, J. (2011). "Microblogging after a major disaster in China: a case study of the 2010 Yushu earthquake." In Proceedings of the ACM 2011 conference on Computer supported cooperative work, CSCW '11, pp. 25-34. ACM.

Qu, Y., Wu, P. F., and Wang, X. (2009). "Online Community Response to Major Disaster: A Study of Tianya Forum in the 2008 Sichuan Earthquake." In HICSS, pp. 1-11. IEEE Computer Society.

佐野大樹. 日本語における修辞ユニット分析の方法と手順 ver.0.1.1一選択体系機能言語理論 (シス 
テミック理論) における談話分析一（修辞機能編）.http://researchmap.jp/systemists/ 資料公開/.

佐野大樹 (2010). 特集選択体系機能言語理論を基底とする特定目的のための作文指導方法につ

いて一修辞ユニットの概念から見たテクストの専門性. 専門日本語教育研究, 12, pp. 19-26. 佐野大樹，小磯花絵 (2011). 現代日本語書き言葉における修辞ユニット分析の適用性の検証一

「書き言葉らしさ・話し言葉らしさ」と脱文脈化言語・文脈化言語の関係一. 機能言語学研 究, 6, pp. 59-81.

佐藤健二 (2007). 関東大震災後における社会の変容. 立命館大学・神奈川大学 21 世紀 COE プ

ログラムジョイントワークショップ報告書『歴史災害と都市一京都・東京を中心に一』， pp. 81-89.

立入勝義 (2011). 検証 東日本大震災そのときソーシャルメディアは何を伝えたか? ディスカ ヴァー・トゥエンティワン。

田中弥生，佐野大樹 (2011). Yahoo!知恵袋における質問と回答の分類一修辞ユニット分析を 用いた脱文脈化一文脈化の程度による検討一。社会言語科学会第 27 回大会発表論文集, pp. 208-211.

田中弥生 (2011). 修辞ユニット分析を用いた Q \& A サイトの質問と回答における修辞機能の展

開の検討. 社会言語科学会第 28 回大会発表論文集, pp. 226-229.

田中弥生，佐野大樹 (2011a). Yahoo!知恵袋における質問の修辞ユニット分析一脱文脈化一文脈 化の程度による分類一. 信学技報, 110 (400), pp. 13-18.

田中弥生, 佐野大樹 (2011b). 修辞ユニット分析からみた Q\&A サイトの言語的特徵. 言語処理 学会第 17 回年次大会 (NLP2011) 論文集, pp. 248-251.

垂水浩幸 (2010). 実世界インタフェースの新たな展開：4.ソーシャルメディアと実世界. 情報 処理学会誌, 51 (7), pp. 782-788.

梅島彩奈, 宮部真衣, 荒牧英治, 灘本明代 (2011). 災害時 Twitter におけるデマとデマ訂正 RT の傾向. 情報処理学会研究報告. データベース・システム研究会報告, 2011 (4), pp. 1-6.

Vieweg, S., Hughes, A. L., Starbird, K., and Palen, L. (2010). "Microblogging during two natural hazards events: what twitter may contribute to situational awareness." In Proceedings of the SIGCHI Conference on Human Factors in Computing Systems, CHI '10, pp. 1079-1088. ACM. 


\section{付録}

\section{A 各評価値における修辞機能と脱文脈化指数の割合}

有害性および有用性の評価值毎に分類された流言に関する修辞機能と脱文脈化指数の割合を, 図 3 および図 4 にそれぞれ示す.

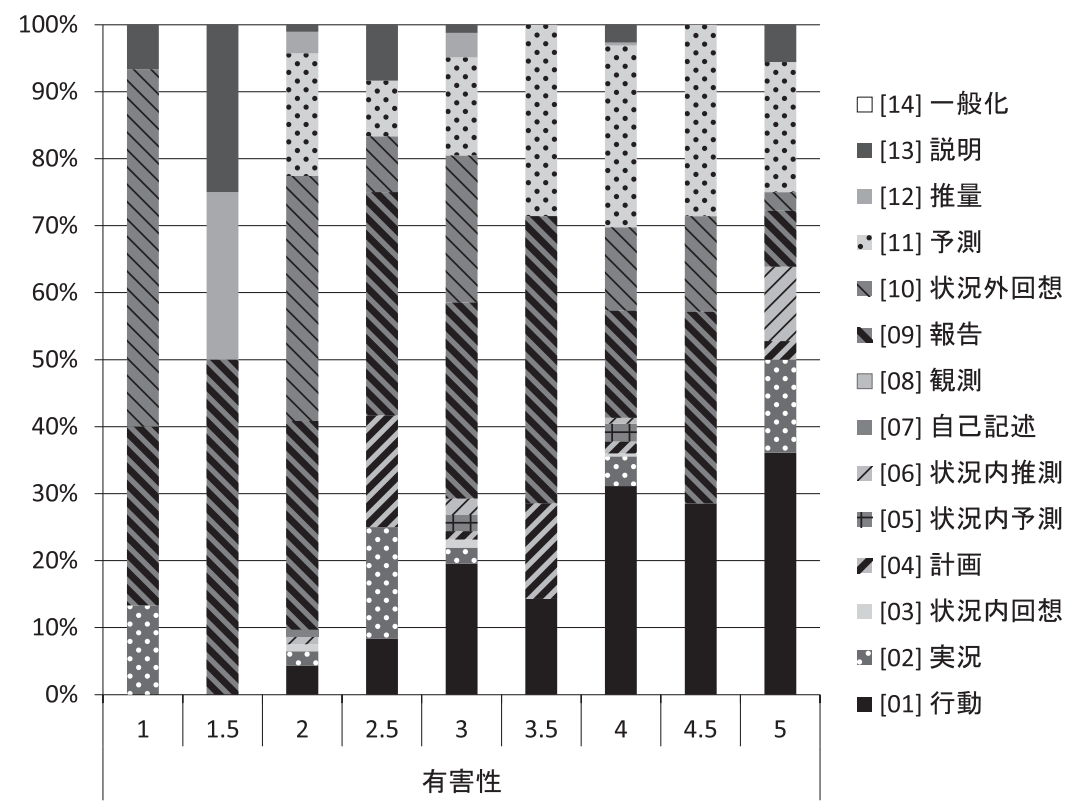

図 3 有害性（各評価値）と修辞機能および脱文脈化指数 


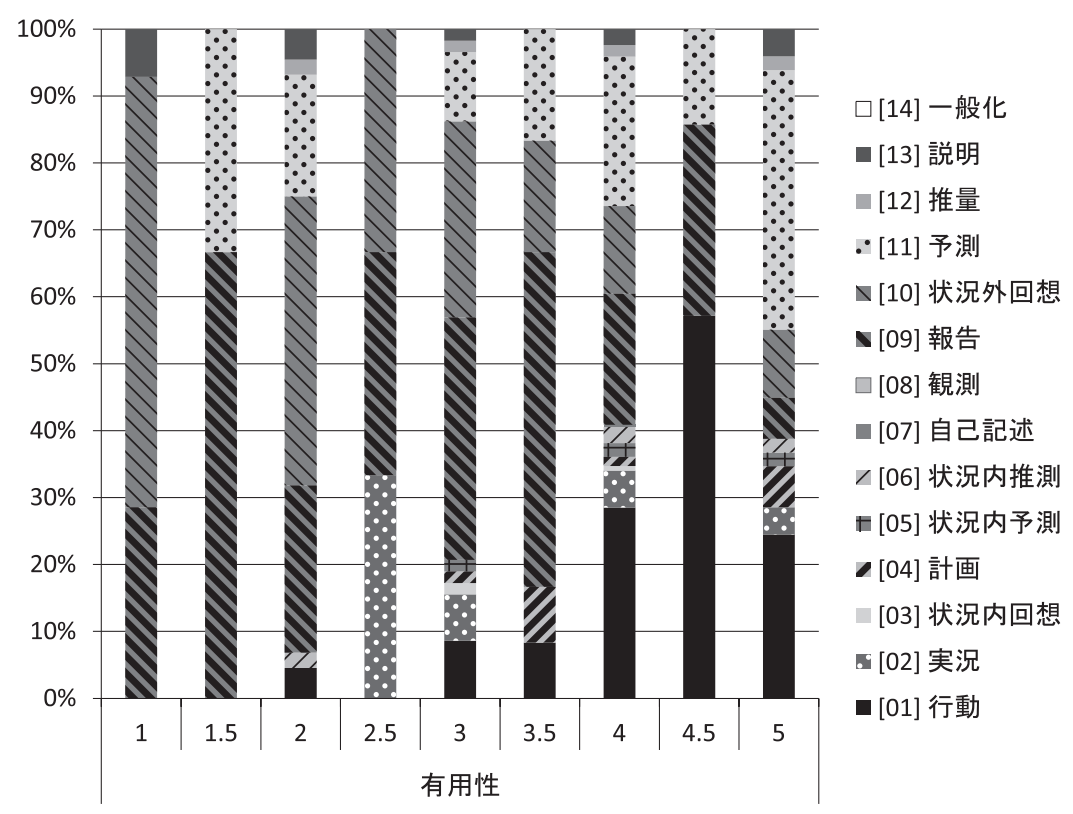

図 4 有用性（各評価値）と修辞機能および脱文脈化指数 


\section{B 1 つの流言に対するテキストを限定した場合の分析結果}

4.4 節で述べた，1つの流言に対するテキストを限定し， 300 件のテキストを用いた場合の分 析結果として, 以下のデータを提示する.

(1) 各主観評価結果の相関係数（表 15, 16）

(2) 修辞機能と脱文脈化指数による分類結果（表 17）

(3) 有害性および有用性の評価值毎に分類された流言に関する修辞機能と脱文脈化指数の割 合（図 5,6)

表 15300 件のテキストにおけり主観評価結果の相関係数（中央值を用いた場合）

\begin{tabular}{l|cc|ccccc}
\hline & 有害性 & 有用性 & ネガティブさ & 行動促進 & 不安扇動 & 尤もらしさ & 伝聞情報 \\
\hline 有害性 & 1.000 & & & & & & \\
有用性 & 0.620 & 1.000 & & & & & \\
ネガティブさ & 0.283 & 0.288 & 1.000 & & & & \\
行動促進 & 0.380 & 0.512 & 0.057 & 1.000 & & & \\
不安扇動 & 0.337 & 0.365 & 0.863 & 0.109 & 1.000 & & \\
尤もらしさ & 0.103 & 0.210 & 0.152 & 0.150 & 0.171 & 1.000 & \\
伝聞情報 & 0.126 & 0.024 & 0.163 & -0.042 & 0.198 & 0.247 & 1.000 \\
\hline
\end{tabular}

表 16300 件のテキストにおける主観評価結果の相関係数（全評価値を用いた場合）

\begin{tabular}{l|rr|rrrrr}
\hline & 有害性 & 有用性 & ネガティブさ & 行動促進 & 不安扇動 & 尤もらしさ & 伝聞情報 \\
\hline 有害性 & 1.000 & & & & & & \\
有用性 & 0.562 & 1.000 & & & & & \\
ネガティブさ & 0.216 & 0.183 & 1.000 & & & & \\
行動促進 & 0.320 & 0.421 & -0.022 & 1.000 & & & \\
不安扇動 & 0.254 & 0.303 & 0.753 & 0.074 & 1.000 & & \\
尤もらしさ & 0.226 & 0.135 & -0.005 & 0.144 & 0.046 & 1.000 & \\
伝聞情報 & 0.162 & 0.044 & 0.112 & 0.021 & 0.138 & 0.209 & 1.000 \\
\hline
\end{tabular}


表 17300 件のテキストにおける修辞機能と脱文脈化指数による分類結果

\begin{tabular}{l|cc}
\hline 修辞機能 ([] 内は脱文脈化指数) & $\begin{array}{c}\text { 該当数 } \\
(\text { 最大值 })\end{array}$ & $\begin{array}{c}\text { 該当数 (最小值) } \\
(\text { 件 })\end{array}$ \\
\hline$[01]$ 行動 & 22 & 45 \\
{$[02]$ 実況 } & 11 & 13 \\
{$[03]$ 状況内回想 } & 3 & 3 \\
{$[04]$ 計画 } & 8 & 8 \\
{$[05]$ 状況内予想 } & 7 & 7 \\
{$[06]$ 状況内推測 } & 7 & 7 \\
{$[07]$ 自己記述 } & 1 & 1 \\
{$[08]$ 観測 } & 0 & 0 \\
{$[09]$ 報告 } & 94 & 90 \\
{$[10]$ 状況外回想 } & 67 & 60 \\
{$[11]$ 予測 } & 54 & 46 \\
{$[12]$ 推量 } & 11 & 8 \\
{$[13]$ 説明 } & 14 & 12 \\
{$[14]$ 一般化 } & 1 & 0 \\
\hline
\end{tabular}

* 修辞ユニット分析は節ごとに分類を行うため, 1 つのツイートに複数の修辞機能が認定され, 脱文脈化 指数が付与される場合がある，そこで，表 17 には 1 つのツイートに付与された脱文脈化指数のうち，最 大值および最小值を代表值とした場合の該当数を提示している. 


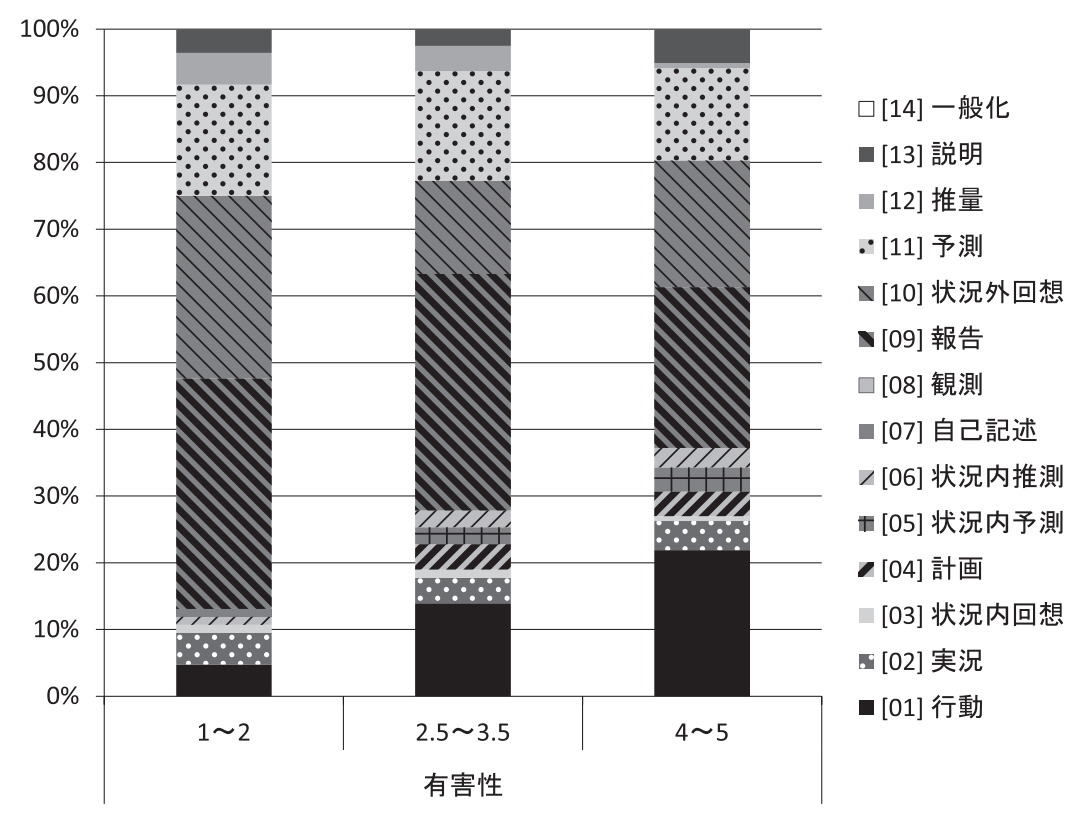

図 5300 件のテキストにおける有害性と修辞機能および脱文脈化指数

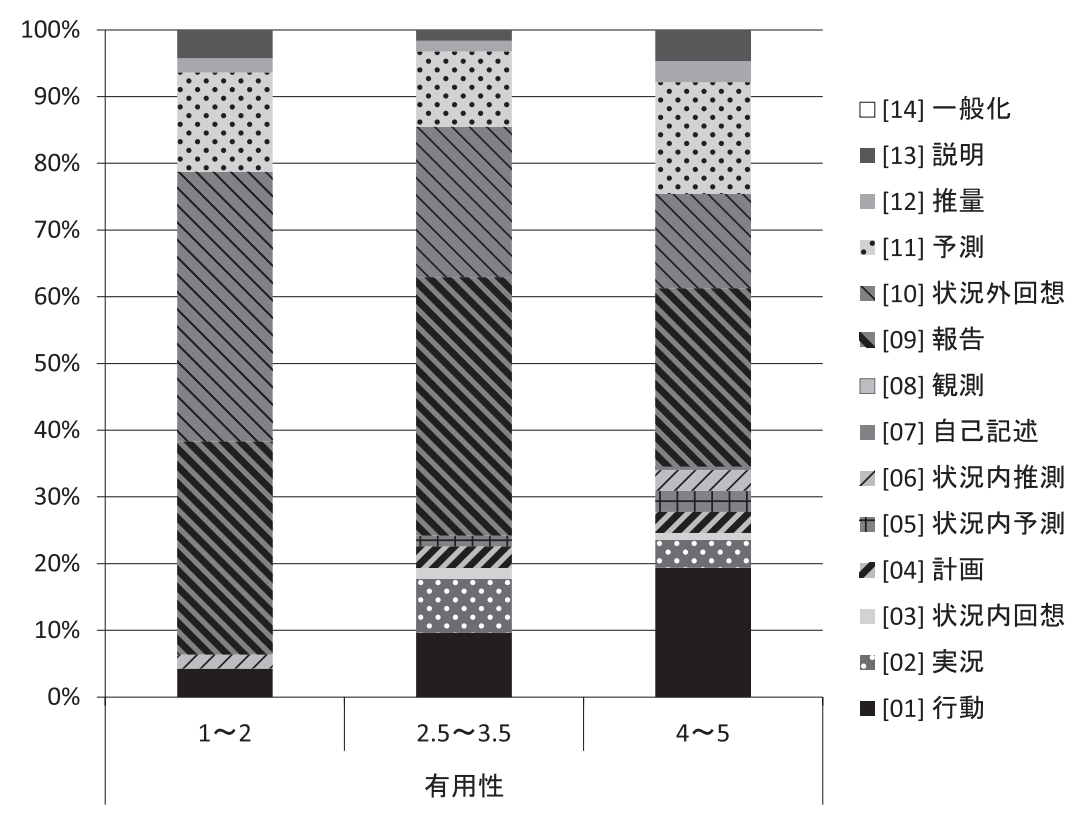

図 6300 件のテキストにおける有用性と修辞機能および脱文脈化指数 


\section{略歴}

宮部 真衣：2006 年和歌山大学システム工学部デザイン情報学科中退. 2008 年 和歌山大学大学院システム工学研究科システム工学専攻博士前期課程修了. 2011 年和歌山大学大学院システム工学研究科システム工学専攻博士後期課程 修了. 博士 (工学). 現在, 東京大学知の構造化センター特任研究員. コミュ ニケーション支援に関する研究に従事.

田中 弥生：1997 年青山学院大学大学文学部第二部英米文学科卒業. 1999 年青 山学院大学大学院国際政治経済学研究科国際コミュニケーション専攻修士課 程修了。修士（国際コミュニケーション学). 現在, 神奈川大学外国語学部, 青山学院女子短期大学非常勤講師. 英語およびコミュニケーション論を担当.

西畑祥：2013 年甲南大学知能情報学部知能情報学科卒業. 在学中は, マイ クロブログ上の流言情報の特徵分析に関する研究に従事.

灘本 明代：東京理科大学理工学部電気工学科卒業. 2002 年神戸大学大学院自 然科学研究科情報メディア科学専攻後期博士課程修了. 博士 (工学). 現在, 甲南大学知能情報学部教授. Webコンピューティング, データ工学の研究に 従事. ACM, IEEE, 情報処理学会, 電子情報通信学会会員.

荒牧 英治： 2000 年京都大学総合人間学部卒業. 2002 年京都大学大学院情報学 研究科修士課程修了. 2005 年東京大学大学院情報理工系研究科博士課程修了 (情報理工学博士). 以降, 東京大学医学部附属病院企画情報運営部特任助教, 東京大学知の構造化センター特任講師を経て, 現在, 京都大学デザイン学ユ ニット特定准教授, 科学技術振興機構さきがけ研究員（兼任）。自然言語処 理, 医療情報学の研究に従事. 